\title{
Analisis Cost-Volume-Profit untuk Perencanaan Laba pada UD. Budi Luhur Demak
}

\author{
ERAWATI KARTIKA \\ PUJI SETYA SUNARKA \\ Fakultas Ekonomika dan Bisnis Universitas AKI \\ Jl Imam Bonjol No. 15-17, Pandansari, Semarang - 50139 \\ email : erawati.kartika@ unaki.ac.id
}

Diterima 1 Maret 2019; disetujui 11 Maret 2019;

\begin{abstract}
Profit is one indicator in evaluating the performance of a company. To achieve the required profit, good profit planning is needed. Because with the existence of better profit planning, the company in controlling costs will be more directed. Cost-volumeprofit analysis (cost-volume-profit) is a very necessary compilation of companies wanting to do profit planning and decision making related to the relationship between costs, sales volume and prices. The purpose of this study was to study how cost-volume-profit in 2015-2016 can be used for income in 2016 at UD. Budi Luhur Demak. The method used was descriptive method. The results of this study indicated that cost-volume-profit analysis from 2015-2016 at UD. Budi Luhur increased profits while sales volume decreased and fixed costs increased. Through this cost-volume-profit analysis, it can be predicted the minimum number of sales that must be achieved to obtain agreed profits in 2016. It is better if company management can apply cost-volume-profit analysis in the profitability.
\end{abstract}

Keywords: analysis of cost-volume-profit, profit planning

\section{PENDAHULUAN}

Latar Belakang. Analisis biaya-volume-laba (CVP) adalah suatu metode untuk menganalisis bagaimana berbagai keputusan operasi dan pemasaran akan memengaruhi laba. Analisis CVP memiliki banyak aplikasi, diantaranya: (1) Menetapkan harga jual produk dan jasa, (2) Memperkenalkan produk atau jasa yang baru, (3) Menggantikan sebuah peralatan, dan (4) Menentukan titik impas. Analisis CVP didasarkan pada model eksplisit mengenai hubungan antara tiga faktorbiaya, penjualan, laba-serta bagaimana perubahan dari ketiga faktor tersebut dengan cara yang dapat diprediksi ketika volume aktivitas juga berubah. Model CVP adalah

Laba Operasi = Penjualan - Total Biaya

Analisis Biaya Volume Laba atau CostVolume-Profit Analysis (CVP Analysis) adalah suatu alat yang bermanfaat untuk mengidentifikasi cakupan dan besarnya keadaan suatu perusahaan dalam membantu mencarikan solusi atau pemecahannya. CVP Analysis ini menekankan keterkaitan antara biaya, kuantitas penjualan dan harga jual, serta semua informasi keuangan yang terkandung di dalamnya. Akuntansi manajemen merupakan sebuah sistem akuntansi yang mempunyai kaitan dengan penggunaan informasi akuntansi oleh tingkat manajerial dalam suatu organisasi. Manfaat akuntansi manajemen itu sendiri adalah akan memberikan dasar pembuatan keputusan bisnis sehingga manajemen bisa lebih siap untuk mengelola dan melakukan fungsi pengontrolan.

Tujuan jangka pendek dari sebuah perusahaan adalah memaksimalkan laba. Untuk bisa mencapai laba yang telah ditargetkan, maka perlu adanya perencanaan laba. Dengan adanya perencanaan laba diharapkan perusahaan dapat mengendalikan 
biaya seefisien mungkin bahkan dapat mengidentifikasi masalah-masalah yang terjadi didalam perusahaan. Untuk membuat perencanaan laba yang baik kita dapat menggunakan analisis costvolume-profit (biaya-volume-laba) sabagai salah satu alat yang dapat digunakan.

Analisa CVP (Cost - Volume - Profit Analysis - CVP Analysis) merupakan suatu alat yang berguna dalam perencanaan dan pengambilan keputusan. Dimana analisis CVP menekankan keterkaitan antara biaya, kuantitas dan harga oleh karena itu semua informasi keuangan perusahaan sangat dibutuhkan. Analisis CVP dapat menjadi alat yang bermanfaat untuk mengidentifikasi cakupan dan besarnya kesulitan ekonomi yang dialami suatu divisi dan membantu mencari pemecahannya, juga dapat digunakan untuk menentukan berapa jumlah unit yang akan dijual untuk mencapai titik impas, selain itu juga dapat melihat dampak pengurangan biaya tetap terhadap titik impas dan dampak kenaikan harga terhadap laba. Analisis tersebut akan menghasilkan nilai contribution margin (marjin kontribusi), break even point (nilai titik impas), margin of safety (tingkat batas keamanan) dan leverage operasi. Analisis cost-volume-profit akan memudahkan perusahaan dalam menentukan target pendapatan dan jumlah biaya yang dikeluarkan dalam upaya mencapai laba yang telah sirencanakan tersebut.

Usaha Dagang Budi Luhur (UD. Budi Luhur) yang berlokasi di daerah Sidomulyo, Demak merupakan usaha dagang yang bergerak dibidang penggilingan padi dalam hal ini pemrosesan gabah menjadi beras. UD. Budi Luhur selama ini memperkirakan laba penjualannya tanpa menggunakan analisis cost-volume-profit, perusahaan hanya membandingkan jumlah yang dikeluarkan dan jumlah yang diterima tanpa ada suatu perencanaan laba. Setiap perusahaan tentunya mengharapkan laba yang tinggi, dengan strategi mengenai biaya dan harga yang tepat sehingga laba yang ditargetkan dapat tercapai setiap tahunnya.

Tujuan Penelitian. Tujuan penelitian ini untuk mengetahui analisis cost-volume-profit UD. Budi Luhur tahun 2016-2017 dan untuk mengetahui perencanaan laba dengan menggunakan analisis cost-volume-profit pada UD. Budi Luhur tahun 2016.

\section{TINJAUAN TEORETIS}

Akuntansi Manajemen. Dalam setiap pengambilan keputusan manajer pasti membutuhkan informasi baik untuk membuat keputusan rutin maupun keputusan khusus. Keputusan rutin adalah keputusan dalam bidang operasi setiap hari, sedangkan keputusan khusus adalah keputusan yang kadangkala diambil, seperti keputusan menambah volume (jumlah unit) produksi, keputusan ekspansi, keputusan penggantian perlatan (mesin), keputusan mengadakan riset pengembangan produk serta riset pasar, dan lain-lain. Semua keputusan tersebut sangat membutuhkan informasi khusunya informasi akuntansi, karena dalam dunia bisnis, semua kejadian atau transaksi dicatat, diklasifikasikan, dikelompokkan, dilaporkan dan diinterpretasikan.

Menurut Chartered Institute of Management Accountants (CIMA), bahwa menurutnya akuntansi manajemen adalah proses identifikasi, pengukuran, akumulasi, analisis, penyusunan, interpretasi, dan komunikasi informasi yang digunakan oleh manajemen untuk merencanakan, mengevaluasi dan pengendalian dalam suatu entitas untuk memastikan dan akuntabilitas penyusunan sumber daya tersebut.

Akuntansi Biaya. Akuntansi Biaya adalah proses pencatatan, penggolongan, peringkasan dan penyajian biaya pembuatan dan penjualan produk jasa dengan cara tertentu serta penafsiran terhadapnya.

Klasifikasi Biaya. Klasifikasi biaya sangat diperlukan untuk mengembangkan data biaya yang dapat membantu pihak manajemen dalam mencapai tujuannya. Menurut Mulyadi (2005) terdapat lima cara penggolongan biaya yaitu diantaranya sebagai berikut:

1. Penggolongan biaya menurut objek pengeluaran: Merupakan dasar penggolongan biaya yang terdiri dari:
a. Biaya bahan baku
b. Biaya tenaga kerja langsung
c. Biaya overhead

2. Penggolongan biaya menurut fungsi pokok dalam perusahaan:

a. Biaya produksi. Merupakan biaya-biaya yang terjadi untuk mengolah bahan baku menjadi produk jadi yang siap untuk dijual. 
b. Biaya pemasaran. Merupakan biaya-biaya yang terjadi untuk melaksanakan kegiatan pemasaran produk.

c. Biaya administrasi dan umum. Merupakan biaya-biaya untuk mengkoordinasikan kegiatan produksi dan pemasaran produk.

3. Penggolongan biaya menurut hubungan biaya dengan sesuatu yang dibiayainya:

a. Biaya langsung. Biaya langsung adalah biaya yang terjadi, yang penyebab satu-satunya adalah karena adanya sesuatu yang dibiayainya. Jika sesuatu yang dibiayainya tersebut tidak ada, maka biaya langsung ini tidak akan terjadi.

b. Biaya tidak langsung. Biaya tidak langsung adalah biaya yang terjadinya tidak hanya disebabkan oleh sesuatu yang dibiayainya. Biaya tidak langsung dalam hubungannya dengan produk disebut dengan istilah biaya produksi tidak langsung atau biaya overhead pabrik (factory overhead costs).

4. Penggolongan biaya menurut perilakunya dalam hubungannya dengan perubahan volume aktivitas:

a. Biaya variabel.Biaya variabel adalah biaya yang jumlah totalnya berubah sebanding dengan perubahan volume kegiatan

b. Biaya semivariabel. Biaya semivariabel adalah biaya yang berubah tidak sebanding dengan perubahan volume kegiatan.

c. Biaya semifixed. Biaya semifixed adalah biaya yang tetap untuk tingkat volume kegiatan tertentu dan berubah dengan jumlah yang konstan pada volume produksi tertentu.

d. Biaya tetap. Biaya tetap adalah biaya yang jumlah totalnya tetap dalam kisar volume kegiatan tertentu.

Fungsi Akuntansi Biaya. Bagi sebuah perusahaan, akuntansi biaya memiliki beberapa fungsi, diantaranya:

1. Penentuan Harga Pokok Produksi atau Jasa (Cost of Good Sold), bagian tugas utama dari akuntansi biaya adalah mencatat, menggolongkan, monitoring dan meringkas seluruh komponen biaya yang berhubungan dengan proses produksi, dari data historis ini dijadikan acuan pihak manajemen dalam penentuan harga pokok produksi.

2. Perencanaan dan Pengendalian Biaya (Forcasting and Controlling), atas dasar data historis dari laporan keuangan tentang seluruh aktifitas biaya dapat dijadikan acuan dalam membuat perencanaan anggaran (Budgeting) kemudian melakukan monitoring terhadap penyimpangan biaya atas anggaran yang telah ditetapkan sehingga meningkatkan efisiensi biaya perusahaan.

Perilaku Biaya. Analisis perilaku biaya mampu memberikan masukan bagi manajemen dalam proses estimasi biaya produksi. Analisis perilaku biaya dapat digunakan sebagai salah satu perangkat bagi manajemen untuk memprediksi biaya yang akan dikeluarkan di masa yang akan datang, menentukan besaran skema biaya beserta pendapatan, serta melakukan analisis sensitivitas. Agar tercipta analisis perilaku biaya yang andal, terlebih dahulu setiap biaya harus diidentifikasi, dipilah, dan dikelompokkan kedalam unsur biaya tetap (fixed cost)dan biaya variabel (variable cost). Biaya tetap (fixed cost) adalah suatu biaya yang konstan dalam total tanpa mempertimbangkan perubahan-perubahan tingkat aktivitas dalam suatu kisaran relevan tertentu. Biaya variabel (variable cost) yaitu biaya yang secara total berubah secara proporsional dengan perubahan dalam tingkat aktivitas. Biaya semivariabel (semivariable cost) yaitu biaya yang didalamnya terdiri dari elemenelemen biaya tetap dan biaya variabel (Samryn, 2012).

Analisis Cost-Volume-Profit. Dalam mengambil keputusan, mana?emen ?ugameli!at lima elemen penting terkait analisis cost volume profit, yaitu:

1. Harga produk yaitu !arga yang ditetapkan di dalam suatu periode tertentu secara konstan.

2. Volume atau tingkat akti\$itas yaitu besarnya produk yang di!asilkan dan direncanakan akan dijual di dalam suatu periode tertentu.

3. Biaya Variabel per unit yaitu besarnya biaya produk yang dibebankan secara langsung padasetiap unit barang yang diproduksi.

4. Total biaya tetap yaitu keseluru!an biaya periodik di dalam suatu periode tertentu.

5. Bauran volume produk yang dijual yaitu proporsi Volume relatif produk-produk perusahaan yangakan dijual. 
Studi mengenai hubungan antara pendapatan, biaya, dan laba dikenal dengan analisis biayavolume-laba (cost-volume-profit). Menurut Garrison, dkk (2006), ada beberapa asumsi yang mendasari analisis cost volume profit yaitu:

1. Harga jual konstan. Harga jual produk atau jasa tidak berubah ketika volume berubah.

2. Biaya adalah linear dan dan dapat secara akurat dibagi menjadi element variable dan tetap. Elemen variable adalah konstan per unit dan elemen tetap adalah konstan secaratotal dalam rentang yang relevan.

3. Dalam perusahaan dengan berbagai produk, bauran penjualan adalah konstan.

4. Dalam perusahaan manufaktur, persediaan tidak berubah. Jumlah unit yang diproduksisama dengan jumlah unit terjual.

Analisis Contribution Margin. Margin kontribusi adalah jumlah yang tersisa dari pendapatan dikurangi beban variabel. Jadi, ini adalah Jumlah yang tersedia untuk menutup beban tetap dan kemudian menjadi laba untuk periode tersebut. Margin kontribusi digunakan dulu untuk menutup beban tetap dan sisanya akan menjadi laba. Jika margin kontribusi tidak cukup untuk menutup beban tetap perusahaan, makaakan terjadi kerugian untuk periode tersebut. Ketika titik impas dicapai, laba bersih akan bertambah sesuai dengan margin kontribusi per unit untuk setiap tambahan produk yang terjual. Untuk memperkirakan pengaruh kenaikan pengaulan yang direncanakan terhadap biaya, manajer cukup mengalikan peningkatan dalam unit yang terjual dengan margin kontribusi yang per unit. Hasilnya akan menggambarkan peningkatan laba yang diharapkan.

Margin Kontribusi adalah selisih antara penjualan dan biaya variabel dari suatu produk atau jasa. Yaitu jumlah uang yang tersedia untuk menutupi biaya tetap dan menghasilkan laba. Menurut Samryn (2012:173) Marjin kontribusi adalah selisih Penjualan dengan Biaya Variabel, sedangkan Rasio margin kontribusi diperoleh dari (marjin kontribusi / Penjualan) $\mathrm{x} \%$.

Analisis Break Even Point. Break event point adalah suatu keadaan dimana dalam suatu operasi perusahaan tidak mendapat untung maupun rugi/impas (penghasilan=total biaya). Untuk menentukan titik impas dalam, maka perlu difokus- kan pada laba operasi yang dihasilkan. Pertama kali yang harus dilakukan adalah menentukan titik impas, kemudian melihat bagaimana pendekatan yang telah digunakan itu dapat dikembangkan untuk menentukan jumlah unit yang harus dijual guna menghasilkan laba yang ditargetkan.

Analisis break even point dapat digunakan untuk membantu menetapkan tujuan perusahaan. Menurut Munawir (2004) manfaat analisis break even point yaitu:1.Analisis break evendan keputusan penambahan investasi.Hasil analisis break even point di samping memberikan gambaran tentang keterkaitan antara biaya, volume (jumlah unit), dan laba selain itu juga dapat membantu dalam memberikan informasi maupun pedoman kepada pihak manajemen dalam memecahkan masalah-masalah lain yang kemungkinan terjadi. Sebagai contoh masalah penambahan atau penggantian fasilitas pabrik atau investasi dalam aktiva tetap. 2 . Analisis break even point dan keputusan menutup usaha. Kegunaan lain dari analisis break even point bagi manajemen adalah membantu dalam pengambilan keputusan menutup usaha atau tidak.

Titik impas ialah volume penjualan dimana jumlah pendapatan dan jumlah bebannya sama, tidak ada laba maupun rugi bersih (Simamora, 2012). Menurut Simamora (2012) untuk menentukan tingkat break even point $(B E P)$ dapat dicari dengan menggunakan 2 metode, yaitu:

1. Metode Persamaan

Penjualan $=$ Biaya variabel + Biaya tetap +0

Setelah titik impas dalam unit penjualan diketahui, titik impas penjualan dalam rupiah dapat dicari dengan mengalikan tingkat unit penjualan impas dengan harga jual per unit.

2. Metode Kontribusi Unit

Titik impas (dalam unit $)=$ Biaya tetap $/$ Marjin kontribusi per unit Titik impas (dalam rupiah) $=$ Biaya tetap / Rasio marjinkontribusi

Analisis Margin of Safety. Munawir (2004) menyatakan bahwa : Margin of safety adalah hubungan atau selisih antara penjualan yang dibudget atau tingkat penjualan tertentu dengan penjualan pada tingkat break even merupakan tingkat keamanan (margin of safety) bagi perusahaan dalam melakukan penurunan penjualan. 
Margin of Safety menentukan seberapa banyak penjualan boleh turun sebelum perusahaan mengalami kerugian. Rumus perhitungannya menurut Samryn (2012): Dinyatakan dalam unit : Total Penjualan - Penjualan Titik Impas Dinyatakan dalam presentase: (Marjin pengaman dalam rupiah / Penjualan) x $100 \%$.

Margin of safety dapat memberikan informasi kepada pihak manajemen perusahaan mengenai berapa jumlah penjualan yang direncanakan boleh turun agar perusahaan tidak menderita kerugian. Apabila penurunan yang terjadi dalam persentase lebih kecil dari ratio batas keamanan, maka pihak manajemen tidak perlu khawatir akan akibatnya.

$$
\begin{aligned}
\text { Margin of safety }= & \frac{\text { Penjualan per Budget }}{\text { Penjualan per Break Event }} \% \\
& \frac{\text { Penjualan per Budget-Penjualan per Break Event }}{\text { Penjualan per Budget }} \%
\end{aligned}
$$

Analisis Leverage Operasi. Leverage operasi digunakan untuk menjawab pertanyaan tentang berapa besarnya kenaikan laba jika terjadi kenaikan penjualan dalam jumlah presentase tertentu. Menurut Simamora (2012) tingkat leverage operasi dapat dihitung dengan menggunakan formula: Tingkat Leverage Operasi = Marjin kontribusi / Laba bersih.

Leverage operasi timbul pada saat perusahaan menggunakan aktiva yang memiliki biayabiaya operasi tetap. Biaya tetap tersebut misalnya biaya penyusutan gedung dan peralatan kantor, biaya asuransi dan biaya lain yang muncul dari penggunaan fasilitas dan biaya manajemen. Dalam jangka panjang, semua biaya bersifat variabel, artinya dapat berubah sesuai dengan jumlah produk yang dihasilkan. Oleh karena itu, dalam analisis ini diasumsikan dalam jangka pendek. Biaya operasi tetap, dikeluarkan agar volume penjualan dapat menghasilkan penerimaan yang lebih besar daripada seluruh biaya operasi tetap dan variabel. Pengaruh yang timbul dengan adanya biaya operasi tetap yaitu adanya perubahan dalam volume penjualan yang menghasilkan perubahan keuntungan atau kerugian operasi yang lebih besar dari proporsi yang telah ditetapkan.

Analisis Target Laba. Perencanaan laba ialah penetapan suatu capaian oleh perusahaan yang memungkinkan berjalannya penjualan produk tanpa mengalami kerugian. Carter (2009). Dalam praktiknya, perencanaan laba menjadi tidak semudah yang diharapkan dikarenakan adanya kekuatan-kekuatan eksternal perusahaan yang dapat memengaruhi suatu bisnis. Carter juga mengemukakan hal tersebut dapat mencakup perubahan dalam teknologi, tindakan pesaing, ekonomi, demografi, selera, serta preferensi pelanggan, prilaku sosial, serta faktor-faktor politik. Perencanaan laba yang tepat dan keputusan yang tepat tergantung pada biaya yang realistis (Kirlioglu \& Baral, 2012).

Penelitian Terdahulu. Analisis cost-volumeprofit (CVP) untuk perencanaan laba pada PT. Saka Agung Abadi di Samarinda Nindy Pratiwi, Elfreda Aplonia Lau,Murfat Effendy. Tujuan dari penelitian ini yaitu untuk mengetahui tingkat break even point agar PT. Saka Agung Abadi tidak mengalami kerugian dan menganalisis pada tingkat penjualan berapa PT. Saka Agung Abadidapat mencapai kenaikan laba sebesar $20 \%$. Alat analisis yang digunakan dalam penelitian ini adalah analisis Cost-Volume-Profit (CVP) yang meliputi analisis Break Even Point dan Analisis Perencanaan Laba. Data diperoleh dengan menggunakan teknik dokumentasi dan observasi. Pelawiten (2014) dengan judul Analisis cost-volume-profit untuk perencanaan laba pada UD. Gladys Bakery. Tujuan penelitian ini untuk mengetahui perhitungan analisis cost-volume-profit selama tahun 2012 pada UD. Gladys Bakery. Metode penelitian yang digunakan adalah metode deskriptif. Hasil penelitian menyebutkan bahwa berdasarkan analisis CVP, diketahui bahwa perusahaan hampir mengalamikerugian.

\section{METODE PENELITIAN}

Jenis Penelitian. Penelitian ini termasuk penelitian deskriptif yaitu penelitian yang digunakan untuk menemukan pengetahuan yang seluasluasnya terhadap objek penelitian pada suatu masa tertentu. Jenis penelitian yang digunakan adalah penelitian deskriptif. Sedangkan menurut Punaji Setyosari ia menjelaskan bahwa penelitian deskriptif adalah penelitian yang bertujuan untuk menjelaskan atau mendeskripsikan suatu keadaan, peristiwa, objek apakah orang, atau segala sesuatu yang terkait dengan variabel-variabel yang bisa dijelas- 
kan baik dengan angka-angka maupun kata-kata. Penelitian deskriptif tidak hanya terbatas pada masalah mengenai pengumpulan dan penyusunan data, tetapi juga mengenai analisis dan interpretasi tentang arti data tersebut.

Lokasi Penelitan. Penelitian dilakukan pada UD. Budi Luhur, yang berlokasi di daerah Sidomulyo, Demak, Jawa Tengah. Penelitian dilakukan pada bulan Januari 2017.

Metode Pengumpulan Data. Jenis data yang digunakan dalam penelitian ini adalah data kuantitatif yang berupa volume penjualan, biaya-biaya yang dikeluarkan, harga jual, presentase kenaikan laba yang diharapkan serta data pendukung berupa gambaran umum perusahaan dan struktur organisasi.

Metode Analisis. Metode analisis dalam penelitian ini yaitu untuk menganalisis contribution margin, break even point, margin of safety, leverage operasi, dan analisa perencanaan laba (target laba) di UD. Budi Luhur Demak.

\section{Analisis Contribution Margin (Marjin Kontribusi)}

Contribution Margin (CM) merupakan selisih antara penjualan dan biaya variable. Menurut Samryn (2012) contribution margin dapat digunakan dengan:

Margin kontribusi=Penjualan-Biaya Variabel

Rasio margin kontribusi=(Marjin Kontribusi / Penjualan). \%

\section{Analisis Break Even Point (Titik Impas)}

Titik impas (break even point) adalah tingkat aktivitas dimana suatu organisasi tidak mendapat laba dan tidak menderita rugi. Rumus perhitungannya Menurut Simamora (2012) :

a. Metode Persamaan

Penjualan $=$ Biaya variabel + Biaya tetap +0

Setelah mendapatkan berapa titik impas dalam unit penjualan maka untuk mencari titik impas penjualan dalam rupiah cukup dengan mengalikan tingkat unit penjualan impas dengan harga jual/unit.

b. Metode Contribusi Unit

Titik impas (unit) = Biaya tetap / Marjin kontribusi per unit Titik impas (rupiah) = Biaya tetap / Rasio marjinkontribusi

3. Analisis Margin of Safety (Batas Keamanan)

Margin of safety dapat memberikan informasi kepada pihak manajemen mengenai berapa jumlah penjualan yang direncanakan dalam hal ini jumlah penjualan boleh turun namun tidak menderita kerugian. Apabila yang terjadi adalah penurunan dalam persentase lebih kecil dari ratio batas keamanan, maka pihak manajemen tidak perlu khawatir akan akibatnya. Atau dapat disimpulkan bahwa margin keamanan (Margin of Safety) adalah kelebihan penjualan yang direncanakan diatas jumlah penjualan titik impas. Rumus perhitungannya:

Dinyatakan dalam unit : Total Penjualan Penjualan Titik Impas

Dinyatakan dalam presentase : (Marjin pengaman dalam rupiah / Penjualan) x $100 \%$

\section{Analisis Leverage Operasi}

Operating leverage merupakan penggunaan aktiva (operasi) perusahaan yang diikuti dengan biaya tetap. Konsep operating leverage diharapkan dapat menganalisis sejauh mana pendapatan penjualan dapat menutup biaya tetap dan biaya variabel. Menurut Fakhrudin (2008), leverage merupakan jumlah utang yang digunakan untuk membiayai / membeli aset-aset perusahaan. Perusahaan yang memilikiutang lebih besar dari equity dikatakan sebagai perusahaan dengan tingkat leverage yang tinggi. Tingkat leverage operasi dapat dihitung dengan menggunakan formula :

Tingkat Leverage Operasi $=$ Marjin kontribusi / Laba bersih

\section{Analisis Perencanaan Laba}

Pengertian perencanaan laba Menurut Supriyono (2000) "perencanaan adalah proses untuk menentukan tujuan organisasi yang akan dicapai perusahaan dan mengatur strategi yang akan dilaksanakan, perencanaan ini dapat disusun untuk jangka pendek atau untuk jangka panjang dan akan dapat dipakai sebagai dasar untuk membandingkan kegiatan perusahaan. Samryn (2012) mengemukakan ada dua metode untuk menghitung target laba, yaitu:

a. Metode persamaan

Target penjualan dalam unit: Penjualan $=$ Biaya variable + Biaya tetap + Laba

Target penjualan dalam Rupiah: Rasio Penjualan $=$ Rasio margin kontribusi + Biaya tetap + Laba 
b. Metode Margin Kontribusi

Penjualan dalam unit $=($ Biaya tetap + Target laba) / Marjin kontribusi per unit Penjualan dalam rupiah $=($ Biaya tetap + Target laba $) /$ Rasio marjin kontribusi

\section{HASIL DAN PEMBAHASAN}

Gambaran Umum Perusahaan. Usaha Dagang (UD) Budi Luhur adalah industri yang bergerak di bidang produksi pintu dan kusen. UD. Budi Luhur berdiri pada tahun 2004 dan didirikan oleh Moeljono. UD. Budi Luhur memproduksi dan menjual beras dengan 1 macam jenis beras.

Volume Penjualan, Volume Biaya, dan Rincian Biaya Variabel. Tabel 1 menunjukkan bahwa total penjualan secara keseluruhan mengalami penurunan dan ini dapat dilihat daritahun 2015 sebesar Rp. 10,952,002,015 menjadi Rp. $8,911,398,015$ di tahun 2016. Untuk jumlah \% penurunan penjualan secara keseluruhan dapat dihitung yaitu sebesar $-18.63 \%$.

Tabel 2 menjelaskan biaya tetap pada UD. Budi Luhuruntuk tahun 2015 sebesar Rp.67.000.000 dan untuk tahun 2016 sebesar Rp.73.000.000. Sedangkan Tabel 3 menunjukkan total biaya variabel yang terjadi pada UD. Budi Luhur tahun 2015 berjumlah Rp. 9,702,383,800 dan pada tahun 2015 berjumlah Rp. 7,812,750,010 dengan demikian biaya variabel pada UD. Budi Luhur dari tahun 2015 dan tahun 2016 mengalami penurunan.

Pembahasan. Hal yang perlu dilakukan sebelum analisis cost-volume-profit adalah membagi biaya ke dalam dua unsur biaya yakni biaya variabel dan biaya tetap. Berdasarkan hasil penelitian di dapatkan marjin kontribusi untuk tahun 2015 sebesar Rp. 1,249,116,200 dengan rasio $11 \%$ dan untuk tahun 2016 sebesar Rp. 1,098,648,005 dengan rasio 12\%. Titik impas untuk tahun 2015 sebesar Rp. 4,864,174,550 dan Rp. $5,231,750,018$ untuk tahun 2016. Hal ini menunjukkan bahwa penjualan UD. Budi Luhur sudah sangat baik dari tahun 2015 sampai tahun 2016 karena telah melebihi dari titik impas, sehingga bisa mendapatkan laba yang maksimal. Batas safety of margin untuk tahun 2015 sebesar 56\% dan untuk tahun 2015 sebesar 41\%. Maksudnya yaitu perusahaan mempunyai tingkat batas keamanan jika terjadi penurunan penjualan sebesar 56\% untuk tahun 2015 dan $41 \%$ untuk tahun 2015. Batas keamanan pada UD. Budi Luhur tergolong cukup baik, karena kemungkinan untuk menderita kerugian kecil. Besarnya penjualan minimal yang diperbolehkan (margin of safety) untuk tahun 2015 adalah Rp.6,087,827,465 dan untuk tahun 2016 sebesar Rp. 5,231,750,018. Untuk tingkat leverage operasi UD. Budi Luhur tahun 2015 sebesar 1.8 yang berarti apabila penjualan naik $1 \%$ maka laba dapat naik sebesar 1.8\% dan tahun 2016 sebesar 2.4 yang berarti apabila penjualan naik sebesar $1 \%$ maka laba akan naik $2.4 \%$.

Hasil wawancara dengan pihak UD. Budi Luhur Demak, perusahaan telah menargetkan laba untuk tahun 2017 sebesar $17 \%$ dari tahun sebelumnya yaitu Rp. 530,768,166 dan estimasi kenaikan biaya tetap sebesar $5 \%$ yaitu Rp.677,250,000, dengan demikian penjualan minimum yang harus dicapai perusahaan sebesar Rp 10,426,335,678.

Tabel 1

Data penjualan UD. Budi Luhur Tahun 2017

\begin{tabular}{|c|c|c|c|c|c|c|}
\hline \multirow[t]{2}{*}{ Produk } & \multicolumn{2}{|c|}{ Unit yangterjual } & \multirow[t]{2}{*}{ Nilai jualper unit } & \multicolumn{2}{|c|}{ Total Penjualan } & \multirow[t]{2}{*}{$\%$} \\
\hline & 2015 & 2016 & & 2015 & 2016 & \\
\hline Beras & 1110 ton & 897 ton & Rp. 9.000/kg & $9,990,000,000$ & $8,073,000,000$ & 18,63 \\
\hline Berambut & 60 rit & 600 rit & Rp. $250.000 /$ rit & $18,500,000$ & $14,950,000$ & \\
\hline Katul & 305 ton & 305 ton & Rp. $2.700 / \mathrm{kg}$ & $943,500,000$ & $823,446,000$ & \\
\hline \multicolumn{4}{|c|}{ Total Penjualan } & $10,952,002,015$ & $8,911,398,015$ & 18,63 \\
\hline
\end{tabular}

Sumber : UD. Budi Luhur(2016) 
Tabel 2

Rincian Biaya Tetap UD. Budi Luhur Selama Tahun 2015-2016

\begin{tabular}{lrr}
\hline Biaya-biaya & Tahun 2015 & \multicolumn{1}{c}{ Tahun 2016 } \\
\hline Biaya Gaji (5 karyawan) & $60,000,000$ & $90,000,000$ \\
& $(3,000,000 \times 12 \times 15)$ & $(3,500,000 \times 12 \times 15)$ \\
Biaya penyusutan mesin & $15,000,000$ & $15,000,000$ \\
\hline Total biaya tetap & $\mathbf{5 5 5 , 0 0 0 , 0 0 0}$ & $\mathbf{6 4 5 , 0 0 0 , 0 0 0}$ \\
\hline Sumber : UD. Budi Luhur(2016) & &
\end{tabular}

Tabel 3

Rincian Biaya Variabel UD. Budi Luhur Selama Tahun 2015-2016

\begin{tabular}{|c|c|c|}
\hline Biaya-biaya & Tahun 2015 & Tahun 2016 \\
\hline Biaya bahan Baku (gabah) & $9,435,000,000$ & $7,624,500,000$ \\
\hline Biaya Rol & $117,937,500$ & $95,306,250$ \\
\hline Biaya Karung 25 kg & $2,308,800$ & $1,865,760$ \\
\hline Biaya solar & $62,437,500$ & $15,548,000$ \\
\hline Biaya Angkut rata-rata/th & $62,900,000$ & $50,830,000$ \\
\hline Biaya pemeliharaan dan perbaikan mesin & $20,100,000$ & $23,200,000$ \\
\hline Biaya listrik & $1,700,000$ & $1,500,000$ \\
\hline Total biaya variabel & $9,702,383,800$ & $7,812,750,010$ \\
\hline
\end{tabular}

Sumber: UD. Budi Luhur(2016)

Tabel 4

Laporan Laba Rugi Kontribusi 2015

\begin{tabular}{lcr}
\hline \multicolumn{4}{c}{ Laporan Laba Rugi Kontribusi } \\
\hline \\
\hline Jenjualan & Jumlah & \% \\
Beban Variabel & Rp $10,952,002,015$ & $100 \%$ \\
Margin Kontribusi & Rp $9,702,383,800$ & $89 \%$ \\
Biaya Tetap & Rp $1,249,618,215$ & $11 \%$ \\
Laba Bersih & Rp $555,000,000$ & \\
\hline Titik Impas & Rp $\quad 694,618,215$ & \\
\hline
\end{tabular}

Tabel 5

Laporan Laba Rugi Kontribusi 2016

\begin{tabular}{lcr}
\hline \multicolumn{4}{c}{ Laporan Laba Rugi Kontribusi } \\
\hline \multicolumn{2}{c}{ Jumlah } & $\%$ \\
\hline Penjualan & Rp. 8,911,398,015 & $100 \%$ \\
Beban Variabel & Rp $7,812,750,010$ & $88 \%$ \\
Margin Kontribusi & Rp $1,098,648,005$ & $12 \%$ \\
Biaya Tetap & Rp $645,000,000$ & \\
Laba Bersih & Rp $453,648,005$ & \\
\hline Titik Impas & Beban Tetap/Rasio CM & Rp. 5,231,750,018 \\
\hline
\end{tabular}




\section{SIMPULAN}

Kesimpulan. Berdasarkan hasil penelitian pada bab sebelumnya, maka dapat ditarik kesimpulan sebagai berikut:

1. Analisis cost-volume-profit pada UD. Budi Luhur sebagai berikut: Marjin kontribusi tahun 2015 lebih besar daripada marjin kontribusi tahun 2016 yang mengakibatkan titik impas untuk tahun 2016 lebih besar daripada titik impas tahun 2015. Meskipun demikian penjualan UD. Budi Luhur telah jauh melebihi titik impas, sehingga mendapatkan laba yang maksimal. Batas keamanan pada UD. Budi Luhur tergolong cukup baik sehingga kemungkinan untuk menderita kerugian kecil.

2. Dalam menargetkan laba UD. Budi Luhur untuk tahun 2016 menentukan sebesar 17\% dari tahun sebelumnya, sedangkan estimasi kenaikan biaya tetapnya sebesar $5 \%$.

Saran. Berdasarkan kesimpulan tersebut penelitian ini memiliki beberapa saran. Saran yang dapat diberikan antara lain:

1. Sebaiknya UD. Budi Luhur untuk kedepannya dalam merencanakan laba harus menggunakan analisis cost-volume-profit.

2. Dalam penerapan analisis cost-volume-profit perusahaan harus menentukan mana biaya-biaya mana yang termasuk kategori biaya tetap dan mana yang termasuk sebagai biaya variabel agar supaya perhitungan CVP analisis dapat diperhitungkan secara tepat.

3. Penelitian selanjutnya dapat dilakukan dengan melakukan perbandingan dengan perusahaan sejenis.

\section{DAFTAR PUSTAKA}

Firmansyah, Iman. 2013. Akuntansi Biaya itu Gampang. Dunia Cerdas, Jakarta.

Garrison, Ray H., Noreen, Eric W., Brewer, Peter C., 2008, Akuntansi Manajerial. Edisi Sebelas. Jakarta : Salemba Empat

Indriantoro, Nur dan Bambang Supomo. 2013. Metodologi Penelitian Bisnis : Untuk Akuntansi \& Manajemen.Edisi Pertama. BPFE, Yogyakarta.

Hansen Mowen Krismiaji dan Aryani. 2011. Akuntansi Manajemen. Edisi Kedua. Sekolah Tinggi Ilmu Manajemen YKPN, Yogyakarta.

Horngern, Charles T., Datar, Srikant M., Foster, George., 2006, Akuntansi Biaya. Edisi Dua Belas. Jakarta : Erlangga

Kotler dan Amstrong, 2009. Manajemen Pemasaran. Edisi 12. PT.Indeks. Jakarta.

Pelawiten, Atika. 2014. Analisis Cost-Volume-Profit untuk Perencanaan Laba pada UD. Gladys Bakery. Jurnal EMBA ISSN 2303-1174 Vol.2 No.2. http://ejournal.unsrat.ac.id/index.php/ emba/article/view/ 5004/4522. Diakses 19 Januari 2016. Hal 1670-1681.

Samryn, L.M. 2012. Akuntansi Manajemen. Edisi Pertama. Kencana,Jakarta.

Simamora, Henry. 2012. Akuntansi Manajemen. Edisi III. Star Gate, Riau.

Widilestariningtyas, Ony., Sri Dewi Anggadini dan Dony. W Firdaus. 2012. Akuntansi Biaya. Graha Ilmu, Yogyakarta. 